\title{
Environmental Parasitology: intestinal helminth parasites of the siganid fish Siganus rivulatus as bioindicators for trace metal pollution in the Red Sea
}

\author{
Zaki M. Al-Hasawi* \\ Biological Sciences Department, Faculty of Science, King Abdulaziz University, PO Box 80203, Jeddah 21589, Saudi Arabia
}

Received 1 October 2018, Accepted 25 February 2019, Published online 6 March 2019

\begin{abstract}
Studies on host-parasite systems as bioindicators for monitoring trace metal pollution in marine environments are still scarce. Here, 11, 14 and 17 infrapopulations of Gyliauchen volubilis (Trematoda: Digenea), Procamallanus elatensis (Nematoda) and Sclerocollum rubrimaris (Acanthocephala), respectively, were collected from the fish Siganus rivulatus (Siganidae) in the Red Sea, from a chronically polluted small bay at Sharm El-Sheikh, South Sinai, Egypt. Water and sediment samples from the bay, tissue samples (intestines, liver, and muscle) from each fish, and samples from each parasite were taken for heavy metal analyses of cadmium and lead. Cadmium concentrations in intestines, liver and muscle of non-infected and infected fishes were much lower than those of lead, and both metal concentrations decreased in the order: liver $>$ intestines $>$ muscle. Cadmium and lead concentrations in the tissues of fishes infected with $G$. volubilis or P. elatensis were slightly lower than those in non-infected ones, while in the tissues of fishes infected with Sc. rubrimaris, they were much lower. Low concentrations of cadmium and lead in $G$. volubilis and $P$. elatensis are associated with their limited ability or capacity to accumulate trace metals. Therefore, bioconcentration factors corresponding to these species were relatively low, and both are herein considered as weak bioindicators. By contrast, high concentrations of cadmium and lead in S. rubrimaris are associated with its high ability to accumulate trace metals. Of the present three host-parasite systems, only the Siganus rivulatus-Sclerocollum rubrimaris system seems to be promising for biomonitoring of metal pollution in the Red Sea.
\end{abstract}

Key words: Siganid fish, Metal pollution, Intestinal helminths, Bioindicators, Red Sea.

Résumé - Parasitologie environnementale : helminthes intestinaux du poisson siganidé Siganus rivulatus comme bioindicateurs de la pollution par les métaux à l'état de traces dans la Mer Rouge. Les études sur les systèmes hôte-parasite utilisés comme bioindicateurs pour surveiller la pollution par les métaux à l'état de traces dans les environnements marins sont encore rares. Ici, 11, 14 et 17 infrapopulations, respectivement de Gyliauchen volubilis (Trematoda : Digenea), Procamallanus elatensis (Nematoda) et Sclerocollum rubrimaris (Acanthocephala), ont été prélevées chez le poisson Siganus rivulatus (Siganidae) en Mer Rouge, dans une petite baie chroniquement polluée à Sharm El-Sheikh, Sinaï Sud, Égypte. Des échantillons d'eau et de sédiments de la baie, des échantillons de tissus (intestin, foie, muscles) de chaque poisson et des échantillons de chaque parasite ont été prélevés pour des analyses de métaux lourds (cadmium et plomb). Les concentrations de cadmium dans l'intestin, le foie et le muscle de poissons infectés et non infectés étaient bien inférieures à celles de plomb, et les concentrations de métaux diminuaient dans l'ordre suivant : foie $>$ intestin $>$ muscle. Les concentrations de cadmium et de plomb dans les tissus des poissons infectés par $G$. volubilis ou $P$. elatensis étaient légèrement réduites par rapport à celles des poissons non infectés, alors qu'elles étaient fortement réduites dans les tissus des poissons infectés par $S$. rubrimaris. Les faibles concentrations de cadmium et plomb chez $G$. volubilis et $P$. elatensis sont associées à leur capacité limitée à accumuler des métaux traces. Ainsi, les facteurs de bioconcentration correspondant à ces espèces étaient relativement faibles et les deux sont considérées ici comme des bioindicateurs faibles. Par contre, les fortes concentrations de cadmium et plomb chez Sc. rubrimaris sont associées à sa grande capacité à accumuler des métaux à l'état de traces. Parmi les trois systèmes hôte-parasite présents, seul le système Siganus rivulatusSclerocollum rubrimaris semble être prometteur pour le suivi biologique de la pollution par les métaux en Mer Rouge.

*Corresponding author: zalhasawy@kau.edu.sa; rhassanine@kau.edu.sa

This is an Open Access article distributed under the terms of the Creative Commons Attribution License (http://creativecommons.org/licenses/by/4.0), which permits unrestricted use, distribution, and reproduction in any medium, provided the original work is properly cited. 


\section{Introduction}

Currently, "Environmental Parasitology" is a well-known scientific field concerned with the interactions between parasites and pollutants in the environment $[18,53]$. In this interesting field, helminth parasites, especially intestinal ones (digenean trematodes, cestodes, nematodes and acanthocephalans) are used as bioindicators for heavy metal pollution in the environment $[18,53]$. These metals include both biologically essential (e.g. $\mathrm{Cu}, \mathrm{Ni}, \mathrm{Zn}$ and $\mathrm{Fe}$ ) and non-biologically essential or toxic metals (e.g. $\mathrm{Cd}, \mathrm{Pb}$ and $\mathrm{Hg}$ ). The first group plays an important role in the metabolic activities of organisms, while the second group is mostly toxic, even in traces under certain conditions $[14,58]$.

Intestinal helminth parasites of fishes are considered good sentinel organisms for the biomonitoring of heavy metal pollution in aquatic environments $[41,51,53]$. Only a few previous studies have shown that digenetic trematodes of freshwater fishes [49] or marine fishes [21, 30] accumulate some metals in concentrations much lower than those accumulated by acanthocephalans and cestodes [42]. Previous studies have also shown that parasitic nematodes mainly accumulate essential metals rather than toxic ones $[6,39,53]$. However, accumulation of these metals appears to be variable and depends on the nematode species. As a result, some authors consider them to be good sentinels for heavy metal pollution in aquatic environments [33, 35, 45], while other authors consider them to be inappropriate sentinels for toxic metal pollution in these environments, especially if environmental concentrations are low [22, 36, 39, 57]. Controversially, acanthocephalans and cestodes are now well documented as good sentinels for heavy metal pollution in aquatic environments, since they have a high accumulation capacity and are able to accumulate different metals, especially toxic metals at high levels [13, 23, 28, 29, $36,39,51-53]$. Generally, most research in this field has been carried out to study host-parasite systems in freshwater ecosystems, but those in marine ecosystems are still scarce [40]. To date, only three studies in this field are known from the Red Sea region $[8,22,23]$. In these studies, five monogenean species, four nematode species and one acanthocephalan species, respectively, from Red Sea fishes were considered good sentinels for the biomonitoring of trace metal pollution in this sea.

In the present study, a sample of siganid fish Siganus rivulatus was collected from a chronically polluted bay in the Red Sea. In this sample, some fish were parasitized only by an intestinal trematode, some were parasitized only by an intestinal nematode, and some were parasitized only by an intestinal acanthocephalan. Cadmium $(\mathrm{Cd})$ and lead $(\mathrm{Pb})$ concentrations in these three different host-parasite systems were measured to elucidate and to compare the abilities of these different helminths to accumulate heavy metals in their body, and consequently their usefulness as bioindicators for trace-metal pollution in the Red Sea.

\section{Materials and methods Ethics}

The sampling reported in this paper complied with the current environmental laws and animal ethics regulations of the Egyptian Environmental Affairs Agency (EEAA).

\section{Sampling and sample preparation}

In June 2018, a sample of 64 specimens of the fish Siganus rivulatus (Teleostei, Siganidae), nearly similar in size (13-17 cm in fork length), were caught by a trawling net in the Red Sea, from a small bay (ca. $1 \mathrm{~km}$ in diameter) known as El-Mena Bay (boat harbour) $\left(27^{\circ} 51.2^{\prime} \mathrm{N}, 34^{\circ} 17^{\prime} \mathrm{E}\right)$, at Sharm El-Sheikh, South Sinai, Egypt. Five water and five sediment samples were taken from different locations along this bay, which is chronically polluted due to massive tourism, and the accumulation of an intensive layer of solid waste and sewage on its bottom, either from land-based activities or other maritime and anthropogenic activities. Additionally, there are about 400 diving boats anchoring in the bay and most of them discharge their wastewater directly into the bay without treatment.

Samples of dorsal muscle, middle intestines and liver were taken from each fish and kept frozen at $-20{ }^{\circ} \mathrm{C}$ until being processed for metal analysis.

The infrapopulation (all individual worms) of Gyliauchen volubilis Nagaty, 1956 (Digenea: Gyliauchenidae), Procamallanus elatensis Fusco et Overstreet, 1979 (Nematoda: Camallanidae) or Sclerocollum rubrimaris Schmidt et Paperna, 1978 (Acanthocephala: Cavisomidae) found in the intestines of each infected fish was perfectly teased out and carefully counted; 20 worms were taken from each infrapopulation as a representative sample, carefully homogenised into a composite, and kept frozen at $-20{ }^{\circ} \mathrm{C}$ until being processed for metal analysis.

To reduce the possibility of sample contamination, all the standard precautions were taken during collection and treatment of samples.

\section{Metal analysis}

Water samples were filtered through a $0.45 \mu \mathrm{m}$ membrane filter and acidified with suprapure $\mathrm{HNO}_{3}$ to $\mathrm{pH}$ less than 2, then analysed directly for the heavy metals $\mathrm{Cd}$ and $\mathrm{Pb}$ in an inductively coupled plasma mass spectrometer (ICP-MS-Perkin Elmer ELAN6100). Standards and blanks were processed similarly. Metal concentrations in water samples are expressed as $\mu \mathrm{g} \mathrm{L}^{-1}$.

Sediment samples were analysed according to Oregioni and Aston [43]. In brief, samples were dried in an oven at $110{ }^{\circ} \mathrm{C}$ for $6 \mathrm{~h}$, and then ground in an agate mortar. One gram of homogenised sample was sieved through a $0.75 \mathrm{~mm}$ sieve and digested by a mixture of concentrated acids $\left(\mathrm{HNO}_{3} / \mathrm{HClO}_{4} /\right.$ $\mathrm{HF}=3 / 2 / 1)$. The residue was then dissolved in $3 \% \mathrm{HCl}(\mathrm{v} / \mathrm{v})$ and its volume made up to $50 \mathrm{~mL}$ in a volumetric flask, and then analysed for the heavy metals in the above-mentioned instrument. Blank digestions were processed in the same way. Metal concentrations in sediments are expressed as $\mathrm{mg} \mathrm{kg}^{-1}$ dry weight.

Fish and parasite tissue samples were analysed according to Zimmermann et al. [60]. After thawing, $150 \mathrm{mg}$ (wet weight) of the homogenised fish tissues or $50 \mathrm{mg}$ of parasites were transferred to a $150 \mathrm{~mL}$ perfluoralkoxy (PFA) vessel. A mixture of $2 \mathrm{~mL} \mathrm{HNO}_{3}\left(65 \%\right.$, suprapure) and $2.5 \mathrm{~mL} \mathrm{H} \mathrm{H}_{2} \mathrm{O}_{2}(30 \%$, suprapure) was added and the vessel was heated for $90 \mathrm{~min}$ at 
Table 1. Cadmium and lead concentrations in certified reference materials, and accuracy and detection limits determined by ICP-MS analyses.

\begin{tabular}{|c|c|c|c|c|c|c|c|c|c|c|}
\hline \multirow[t]{2}{*}{ Metal } & \multicolumn{3}{|c|}{$\begin{array}{l}\text { CRM-NIST } 1640 \text { - Trace elements in } \\
\text { natural water }\end{array}$} & $\begin{array}{r}\text { Standarc } \\
\text { HISS-1 }\end{array}$ & $\begin{array}{l}\text { reference ma } \\
\text { - Marine sed }\end{array}$ & $\begin{array}{l}\text { erial } \\
\text { nents }\end{array}$ & \multicolumn{3}{|c|}{ Dogfish muscle-DORM2 } & \multirow{2}{*}{$\begin{array}{c}\text { Detectiōh } \\
-\quad \text { limit } \\
\text { mg kg }\end{array}$} \\
\hline & $\begin{array}{l}\text { Certified } \\
\text { value } \\
\left(\mathrm{mg} \mathrm{L}^{-1}\right)\end{array}$ & $\begin{array}{l}\text { Recovered } \\
\text { value } \\
\left(\mathrm{mg} \mathrm{L}^{-1}\right)\end{array}$ & $\begin{array}{c}\text { Accuracy } \\
(\%)\end{array}$ & $\begin{array}{l}\text { Certified } \\
\text { value } \\
\text { (mg kg } \\
\text { dry wt) }\end{array}$ & $\begin{array}{l}\text { Recovered } \\
\text { value } \\
\text { (mg kg } \\
\text { dry wt) }\end{array}$ & $\begin{array}{l}\text { Accuracy } \\
(\%)\end{array}$ & $\begin{array}{l}\text { Certified } \\
\text { value } \\
\text { (mg kg } \\
\text { wet wt) }\end{array}$ & $\begin{array}{c}\text { Recovered } \\
\text { value } \\
\text { (mg kg } \\
\text { wet wt) }\end{array}$ & $\begin{array}{c}\text { Accuracy } \\
(\%)\end{array}$ & \\
\hline$\overline{\mathrm{Cd}}$ & $3.961 \pm 0.072$ & $3.848 \pm 0$. & 97.14 & $0.024 \pm 0.00$ & $0.022 \pm 0$ & 91.66 & $0.043 \pm 0$. & $.042 \pm 0$ & 397.67 & 0.003 \\
\hline $\mathrm{Pb}$ & $12.005 \pm 0.040$ & $11.526 \pm 0.10$ & 99.00 & $3.140 \pm 0.04$ & $3.008 \pm 0.0$ & 95.79 & $0.065 \pm 0$. & $.063 \pm 0$ & 696.92 & 0.006 \\
\hline
\end{tabular}

Table 2. Range and mean $\mathrm{Cd}$ and $\mathrm{Pb}$ concentrations in the water and sediments at five sites in El-Mena Bay (Red Sea).

\begin{tabular}{|c|c|c|c|c|}
\hline & \multicolumn{2}{|c|}{ Water $\left(\mu \mathrm{g} \mathrm{L}^{-1}\right)$} & \multicolumn{2}{|c|}{ Sediment (mg kg ${ }^{-1}$ dry wt) } \\
\hline & $\mathrm{Cd}$ & $\mathrm{Pb}$ & $\mathrm{Cd}$ & $\mathrm{Pb}$ \\
\hline Range & $0.097-0.118$ & $3.142-4.261$ & $0.295-0.402$ & $9.112-13.315$ \\
\hline Mean $\pm \mathrm{SD}$ & $0.107 \pm 0.008$ & $3.769 \pm 0.492$ & $0.341 \pm 0.039$ & $10.932 \pm 1.646$ \\
\hline
\end{tabular}

about $170{ }^{\circ} \mathrm{C}$ in a microwave digestion system (CEM GmbH, Kamp-Lintfort, Germany; Model MDS-2000). After digestion, the resulting solution was diluted to $5 \mathrm{~mL}$ with high-quality deionised water in a volumetric glass flask, and then analysed for the heavy metals in the above-mentioned instruments. Standards and blanks were processed similarly. Metal concentrations in tissues are expressed as $\mathrm{mg} \mathrm{kg}^{-1}$ wet weight.

Three standard reference materials were used to test the quality of the analytical procedures: 1) CRM-NIST 1640 Trace Elements in Natural Water-National Institute of Standards and Technology, USA, 2) HISS-1-Marine Sediments - National Research Council, Canada, and 3) Dogfish muscleDORM2 - National Research Council, Canada. Analytical blanks were prepared to determine the detection limits.

\section{Data analysis}

Linear regression analyses were used to determine possible relationships between metal concentrations in the parasite body and their concentrations in fish intestines, metal concentrations in fish intestines and parasite infrapopulation size, and between metal concentrations in the parasite and its infrapopulation size. The Graph Pad PRISM 7.0 statistical package (GraphPad Software, San Diego, CA 92037, USA) was used for data analyses. The bioconcentration factor (BCF) or the ratio of metal concentration in the parasite and the host tissue $\left(C_{\text {[parasite] }} / C_{\text {[host tissue] }}\right)$ was calculated as recommended by Sures et al. [55].

\section{Results}

Of the 64 Siganus rivulatus examined, 15 (23.43\%) were free from any intestinal helminth parasites, while the other 49 $(76.57 \%)$ were infected with at least one of three different intestinal helminths: Gyliauchen volubilis Nagaty, 1956 (Trematoda: Gyliauchenidae) [41], Procamallanus elatensis Fusco et Overstreet, 1979 (Nematoda: Camallanidae) [17], and Sclerocollum rubrimaris Schmidt et Paperna, 1978
(Acanthocephala: Cavisomidae) [48]. All patterns of single and concurrent infections (double or triple) with these parasites were found in the infected fishes: $11(17.19 \%)$ with G. volubilis only, $14(21.88 \%)$ with P. elatensis only, 17 (26.56\%) with S. rubrimaris only, 3 (4.69\%) with G. volubilis and P. elatensis, $1(1.56 \%)$ with $G$. volubilis and S. rubrimaris, $2(3.13 \%)$ with $P$. elatensis and S. rubrimaris, and $1(1.56 \%)$ with $G$. volubilis, $S$. rubrimaris and $P$. elatensis. Fishes with single infection contained large numbers of worms (32-210 worm/fish), while those with concurrent infections contained few numbers of worms (4-13 worm/fish) and were excluded from the study to avoid confusion.

Accordingly, 11, 14 and 17 infrapopulations of G. volubilis, P. elatensis and S. rubrimaris ranging from 63 to 159,55 to 179 and from 32 to 210 individuals, respectively, were collected from the infected fishes for metal analyses.

Cadmium and lead concentrations recovered from standard reference materials, the accuracy of the analytical procedures, and the detection limits of each element are shown in Table 1.

\section{$\mathrm{Cd}$ and $\mathrm{Pb}$ concentrations in water and sediment samples from the bay}

Mean $\mathrm{Cd}$ and $\mathrm{Pb}$ concentrations in the sediments were much greater than those in water (Table 2), and permanent $\mathrm{Pb}$ concentrations were greater than those of $\mathrm{Cd}$.

\section{$\mathrm{Cd}$ and $\mathrm{Pb}$ concentrations in selected tissues of non-infected and infected fishes}

Mean $\mathrm{Cd}$ and $\mathrm{Pb}$ concentrations in the intestines, liver and muscle of non-infected and infected individuals of the fish S. rivulatus (with $G$. volubilis, P. elatensis or with S. rubrimaris) are shown in Table 3. In all cases, mean Cd concentrations in these tissues were much lower than those of $\mathrm{Pb}$, and concentrations of both metal decreased in the order: liver $>$ intestines $>$ muscle. 


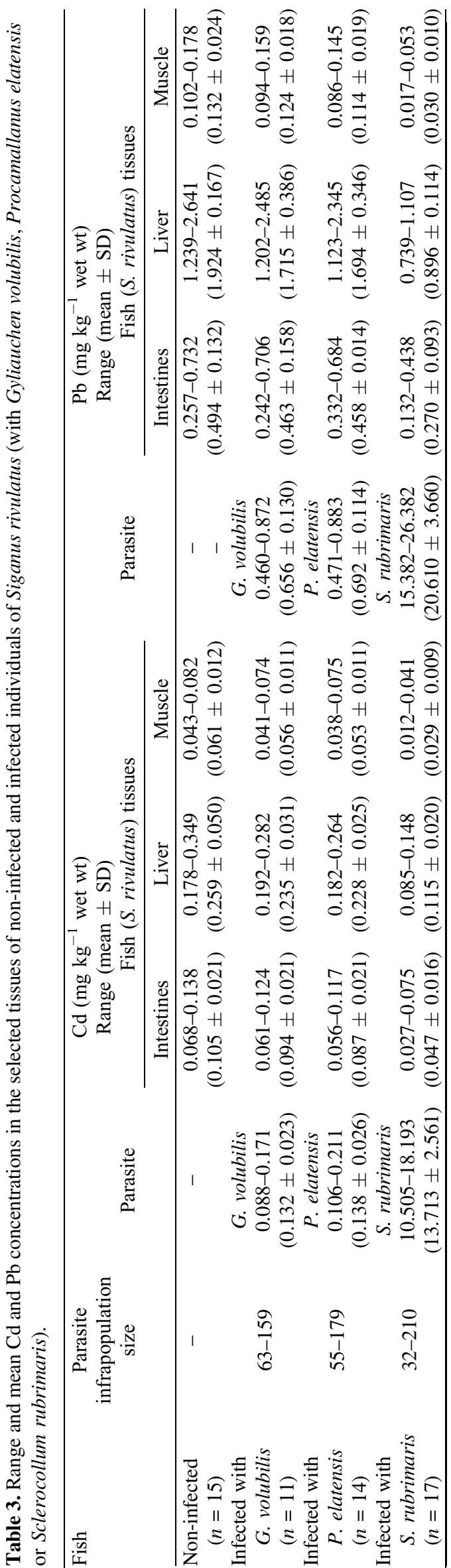

As shown in Table 3, mean $\mathrm{Cd}$ and $\mathrm{Pb}$ concentrations in the intestines, liver and muscle of fishes infected with $G$. volubilis or with $P$. elatensis were slightly lower than those in noninfected fishes, but in fishes infected with $S$. rubrimaris these concentrations were much lower than those in non-infected fishes. These results clearly indicate that metal accumulation in fish tissues was slightly reduced due to infection with the trematode $G$. volubilis or with the nematode $P$. elatensis, but dramatically reduced due to infection with the acanthocephalan S. rubrimaris.

\section{$\mathrm{Cd}$ and $\mathrm{Pb}$ concentrations in helminth parasites}

Cadmium and $\mathrm{Pb}$ concentrations were calculated for 11,14 and 17 infrapopulations of $G$. volubilis, P. elatensis and S. rubrimaris, respectively (Table 3 ). As shown in this table, mean $\mathrm{Cd}$ and $\mathrm{Pb}$ concentrations in the body of $G$. volubilis or in the body of $P$. elatensis were slightly higher than those in the intestines of their fish hosts. However, no significant relationships were found between $\mathrm{Cd}$ or $\mathrm{Pb}$ concentrations in $G$. volubilis and their concentrations in fish intestines $\left(R^{2}=0.09458\right.$, slope $=0.2352, p=0.3576 ; R^{2}=0.1105$, slope $=$ $0.4044, p=0.3179$, respectively) (Fig. 1A and B), or between $\mathrm{Cd}$ or $\mathrm{Pb}$ concentrations in $P$. elatensis and their concentrations in fish intestines $\left(R^{2}=0.06052\right.$, slope $=0.1979, p=0.3965$; $R^{2}=0.0364$, slope $=-0.200, p=0.5136$, respectively) (Fig. 1C and D). Also, no significant relationships between $\mathrm{Cd}$ and $\mathrm{Pb}$ concentrations in fish intestines and $G$. volubilis infrapopulation size were found $\left(R^{2}=0.03252\right.$, slope $=0.00013$, $p=0.5957 ; R^{2}=0.00736$, slope $=0.00046, p=0.8014$, respectively) (Fig. 2A and B), or between $\mathrm{Cd}$ or $\mathrm{Pb}$ concentrations in G. volubilis and its infrapopulation size $\left(R^{2}=0.02295\right.$, slope $=$ $0.00014, p=0.6591 ; R^{2}=0.1265$, slope $=0.00158, p=0.283$, respectively) (Fig. 3A and B). Similarly, no significant relationships between $\mathrm{Cd}$ and $\mathrm{Pb}$ concentrations in fish intestines and $P$. elatensis infrapopulation size were demonstrated $\left(R^{2}=\right.$ 0.08486 , slope $=0.00015, p=0.3123 ; R^{2}=0.2045$, slope $=-0.00139, p=0.1045$, respectively) (Fig. 2C and D), or between $\mathrm{Cd}$ or $\mathrm{Pb}$ concentrations in $P$. elatensis and its infrapopulation size $\left(R^{2}=0.04015\right.$, slope $=0.00014, p=$ $0.2922 ; R^{2}=0.00124$, slope $=-0.00185, p=0.9905$, respectively) (Fig. 3C and D). These non-significant relationships mean that there is no evidence for interspecific competition (between the fish host and G. volubilis or P. elatensis) or intraspecific competition (among parasite individuals) for accumulating these metals. Moreover, mean $\mathrm{Cd}$ and $\mathrm{Pb}$ concentrations in G. volubilis and $P$. elatensis were distinctly lower than those in the fish liver, and a few-fold higher than those in fish muscle (Table 4). A combination of the results clearly indicates that both $G$. volubilis and $P$. elatensis have a limited ability to accumulate heavy metals in their bodies.

Unlike those in G. volubilis and P. elatensis, $\mathrm{Cd}$ and $\mathrm{Pb}$ concentrations in $S$. rubrimaris were significantly high and much higher, respectively than those in the intestines of its fish host (Table 4). However, there were significant positive relationships between $\mathrm{Cd}$ or $\mathrm{Pb}$ concentrations in $\mathrm{S}$. rubrimaris and their concentrations in fish intestines $\left(R^{2}=0.7414\right.$, slope $=0.00552$, $p<0.0001 ; R^{2}=0.6915$, slope $=0.02132, p<0.0001$, respectively) (Fig. $1 \mathrm{E}$ and $\mathrm{F}$ ), i.e. as the $\mathrm{Cd}$ and $\mathrm{Pb}$ concentrations in 
A

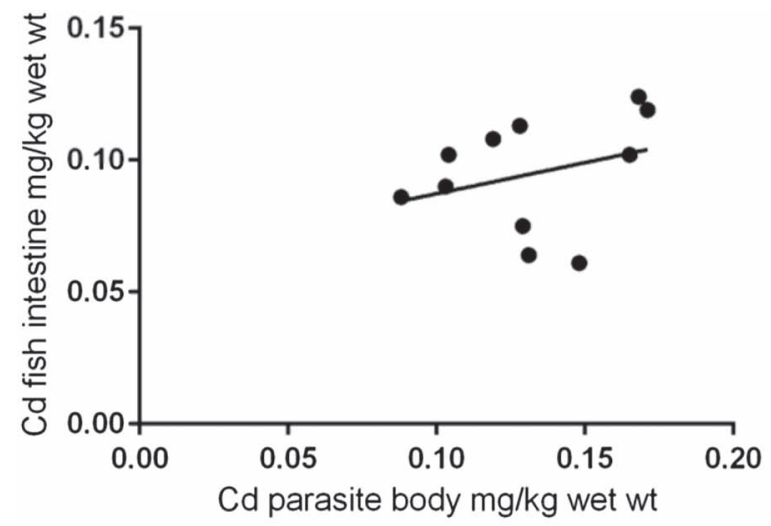

C

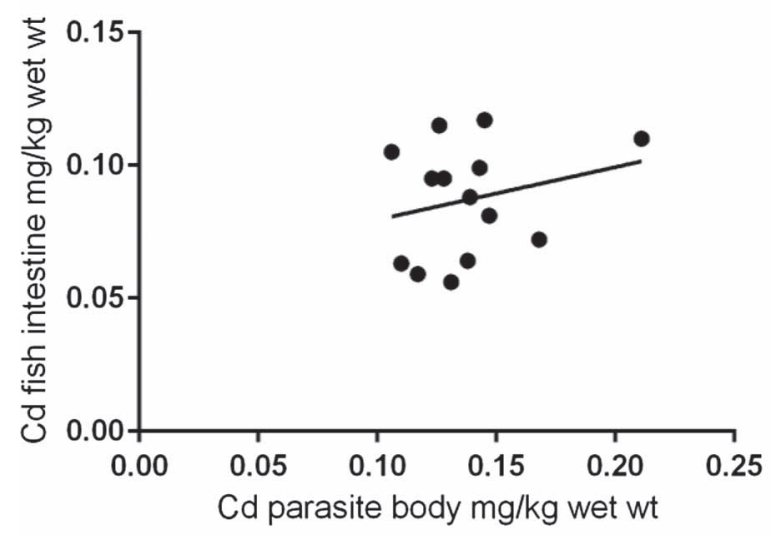

E

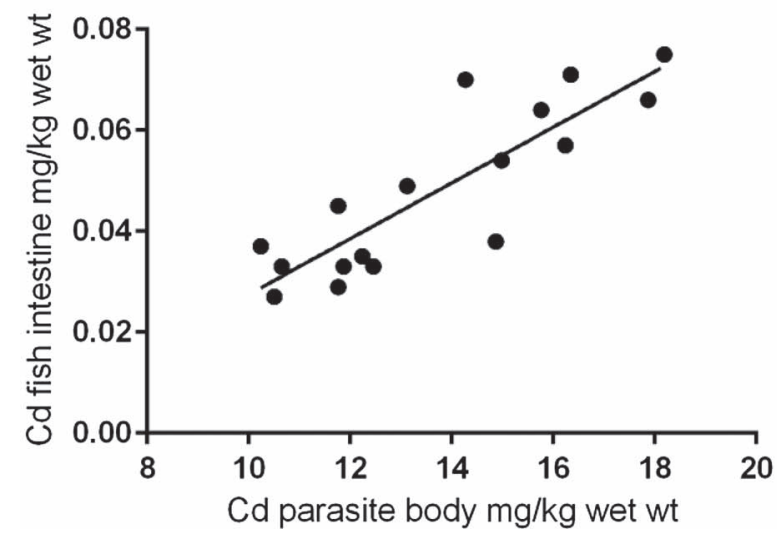

B

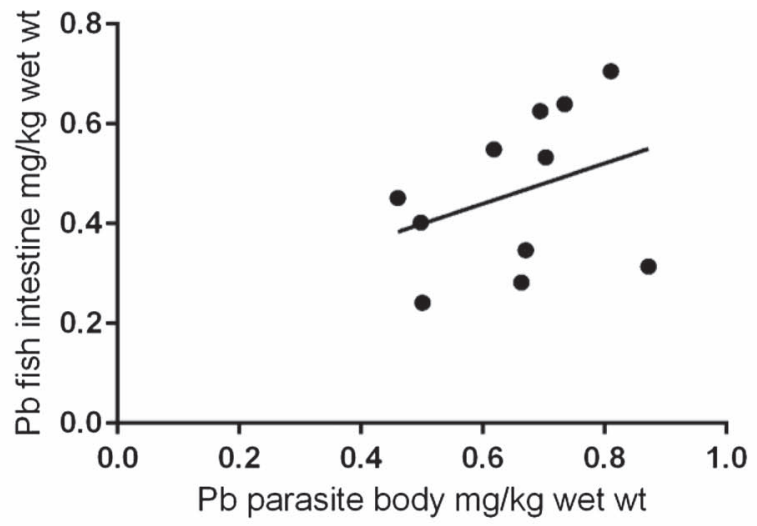

D

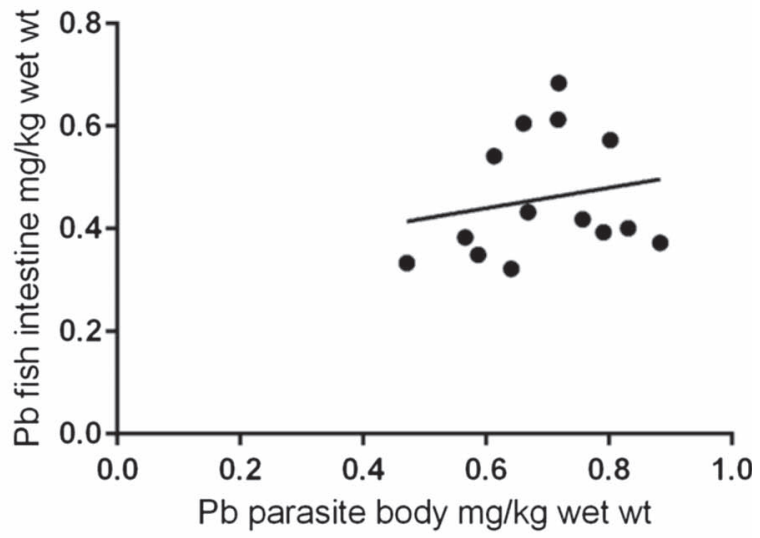

F

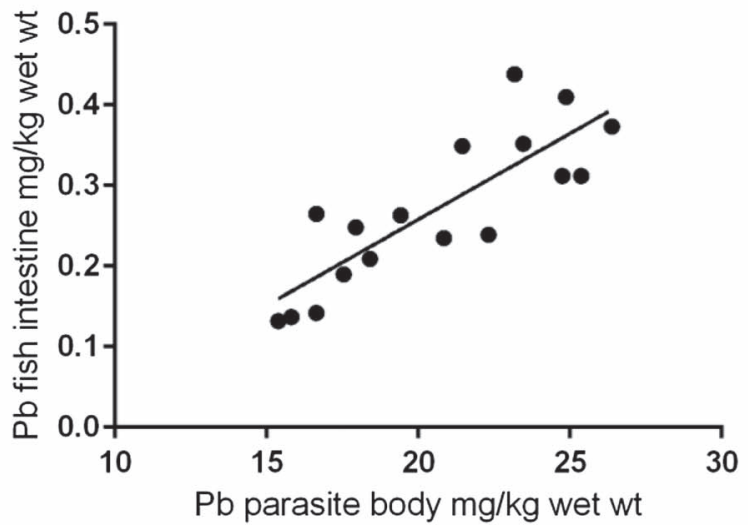

Figure 1. The relationships between metal concentrations in fish intestines and their concentrations in intestinal helminth parasites: (A) Cd concentrations in fish intestines vs. concentrations in G. volubilis; (B) Pb concentrations in fish intestines vs. concentrations in G. volubilis; (C) Cd concentrations in fish intestines vs. concentrations in P. elatensis; (D) Pb concentrations in fish intestines vs. concentrations in P. elatensis; (E) Cd concentrations in fish intestines vs. concentrations in S. rubrimaris; and (F) $\mathrm{Pb}$ concentrations in fish intestines vs. concentrations in S. rubrimaris.

fish intestines increased, their concentrations in the parasite body increased. There were strong negative relationships between $\mathrm{Cd}$ or $\mathrm{Pb}$ concentrations in fish intestines and $S$. rubrimaris infrapopulation size $\left(R^{2}=0.8026\right.$, slope $=-0.00026$, $p<0.0001 ; R^{2}=0.7742$, slope $=-0.001469, p<0.0001$, respectively) (Fig. $2 \mathrm{E}$ and $\mathrm{F}$ ), i.e. as the infrapopulation size of $S$. rubrimaris in the intestines of $S$. rivulatus increases, the concentrations of both $\mathrm{Cd}$ and $\mathrm{Pb}$ in fish intestines significantly 
A

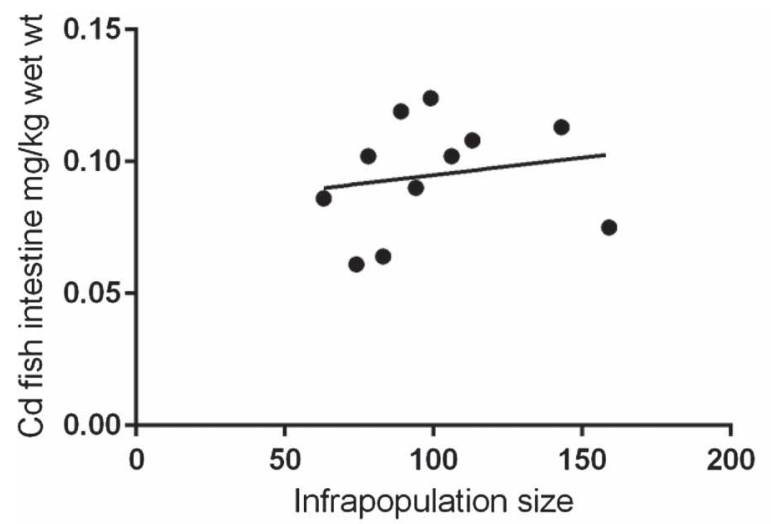

C

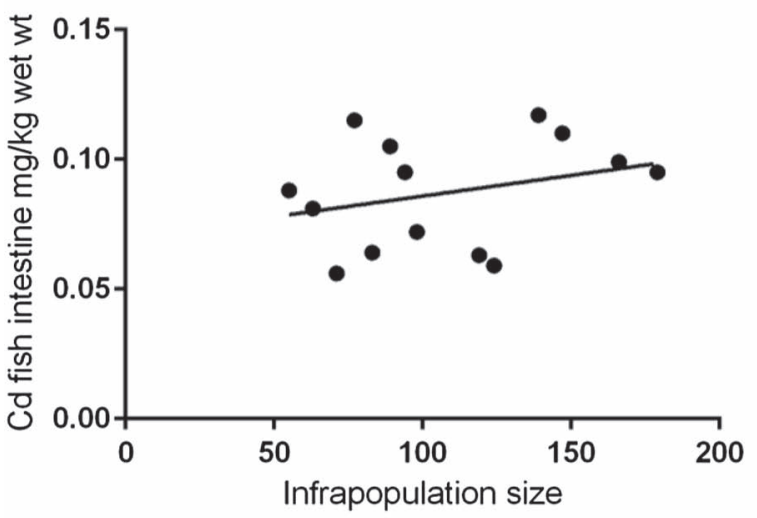

$\mathbf{E}$

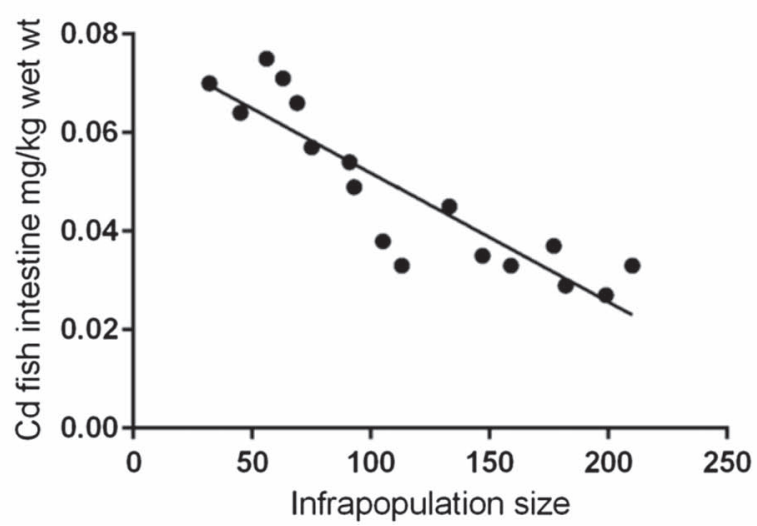

$\mathbf{B}$

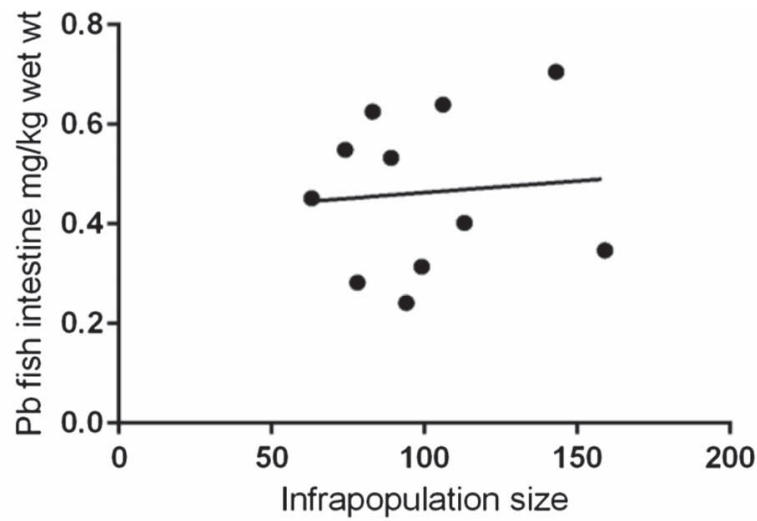

D

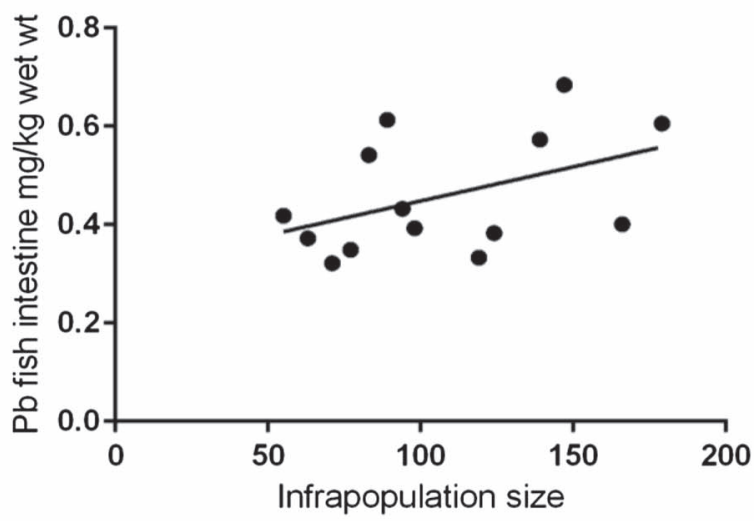

F

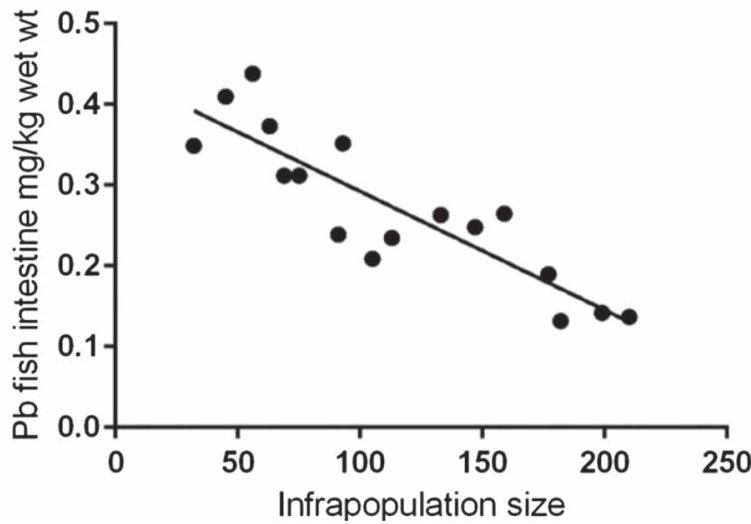

Figure 2. The relationships between metal concentrations in the intestines of infected fish and parasite infrapopulation size in its intestines. (A) $\mathrm{Cd}$ concentrations in fish intestines vs. G. volubilis infrapopulation size; (B) $\mathrm{Pb}$ concentrations in fish intestines vs. G. volubilis infrapopulation size; (C) Cd concentrations in fish intestines vs. P. elatensis infrapopulation size; (D) $\mathrm{Pb}$ concentrations in fish intestines vs. P. elatensis infrapopulation size; (E) Cd concentrations in fish intestines vs. S. rubrimaris infrapopulation size; and (F) $\mathrm{Pb}$ concentrations in fish intestines vs. S. rubrimaris infrapopulation size.

decrease. Also, there were strong negative relationships between $\mathrm{Cd}$ or $\mathrm{Pb}$ concentrations in S. rubrimaris and its infrapopulation size $\left(R^{2}=0.7383\right.$, slope $=-0.03915$, $p<0.0001 ; R^{2}=0.7749$, slope $=-0.05733, p<0.0001$, respectively) (Fig. $3 \mathrm{E}$ and F), i.e. as the infrapopulation size of S. rubrimaris increased, the concentration of both $\mathrm{Cd}$ and $\mathrm{Pb}$ 
A

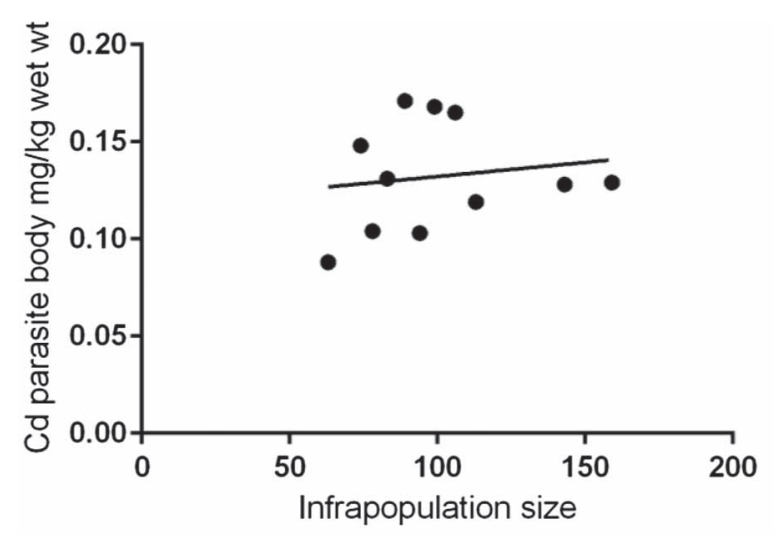

C

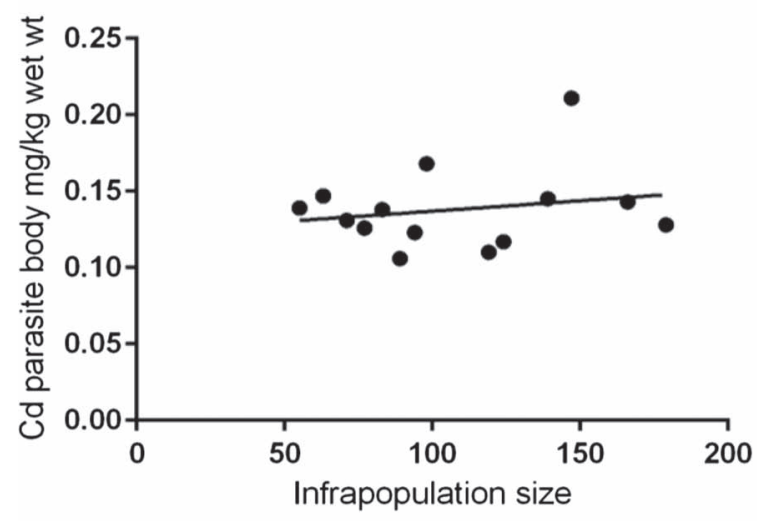

$\mathbf{E}$

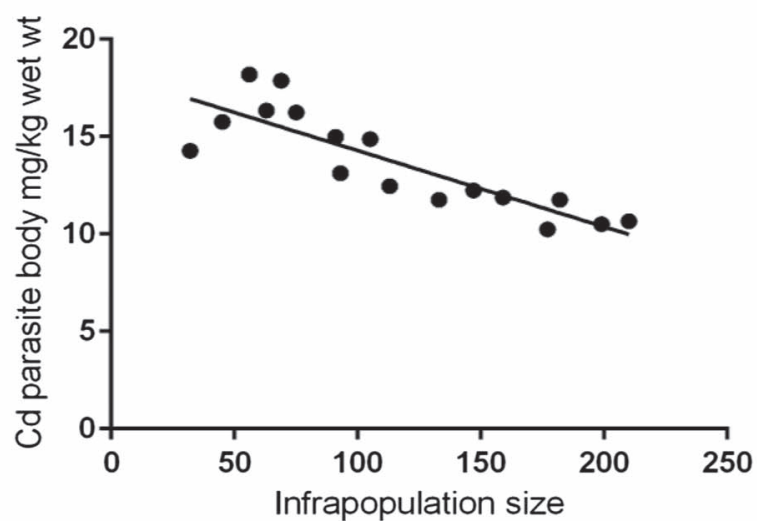

B

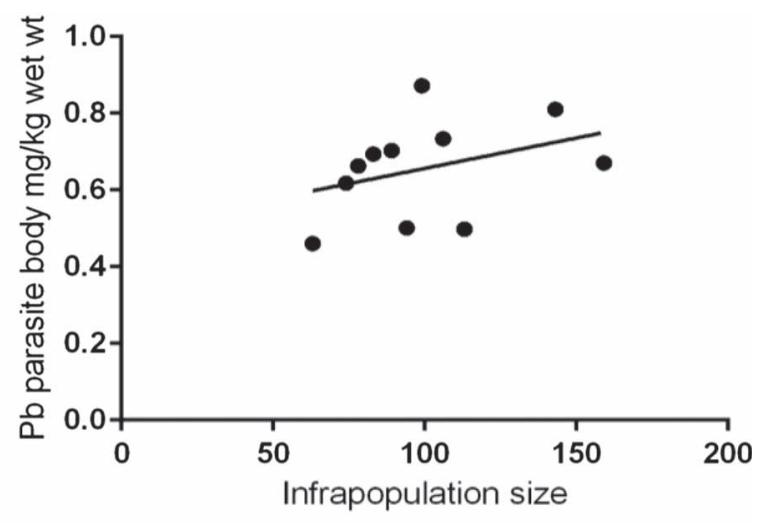

D

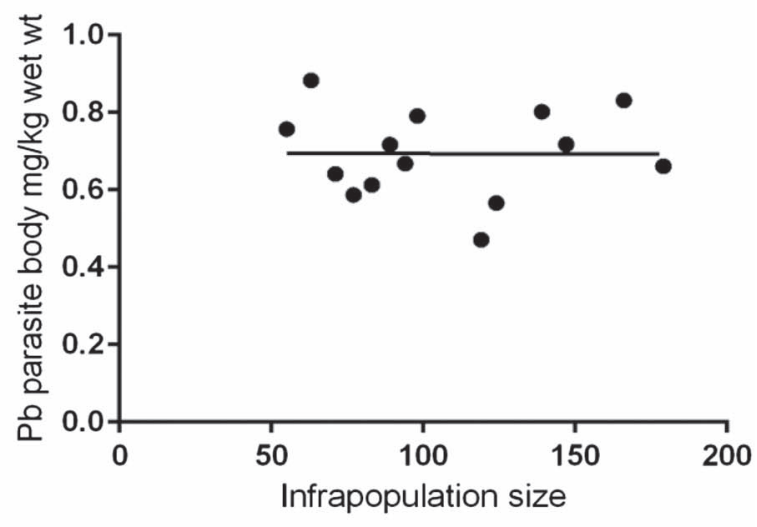

$\mathbf{F}$

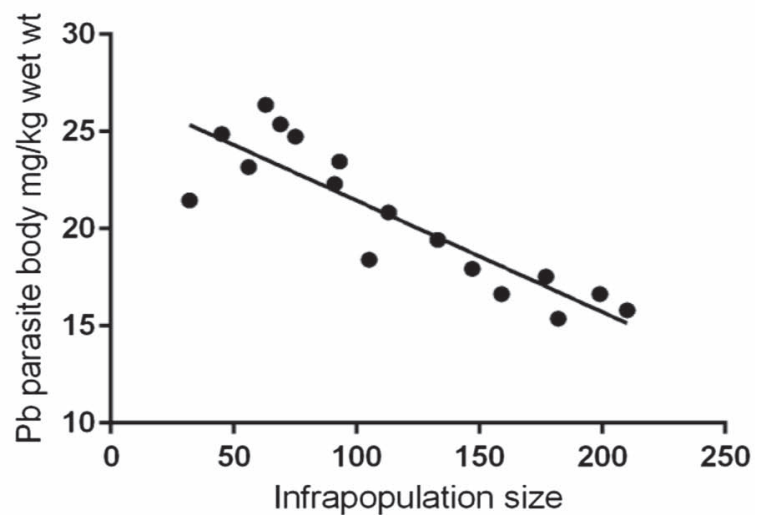

Figure 3. The relationships between metal concentrations in parasites and infrapopulation size in fish intestines: (A) Cd concentrations in $G$. volubilis vs. infrapopulation size; and (B) $\mathrm{Pb}$ concentrations in G. volubilis vs. infrapopulation size; (C) Cd concentrations in P. elatensis vs. infrapopulation size; (D) $\mathrm{Pb}$ concentrations in P. elatensis vs. infrapopulation size; (E) Cd concentrations in S. rubrimaris vs. infrapopulation size; and (F) $\mathrm{Pb}$ concentrations in $S$. rubrimaris vs. infrapopulation size.

in its individuals significantly decreased. Therefore, metal concentrations in this acanthocephalan seem to be mainly associated with those in fish intestines and with its infrapopulation size. Generally, high concentrations of $\mathrm{Cd}$ and $\mathrm{Pb}$ in the body of $S$. rubrimaris clearly indicate that this acanthocephalan has a high ability or capacity to accumulate heavy metals in its body.

Mean $\mathrm{Cd}$ and $\mathrm{Pb}$ concentrations in the body of $G$. volubilis or $P$. elatensis were slightly higher than those in fish intestines, distinctly lower than those in fish liver, and a few-fold higher 
Table 4. Range and mean bioconcentration factors-BCF $\left[=\left(C_{\text {[parasite] }} / C_{\text {[host tissue }]}\right)\right]$ for $\mathrm{Cd}$ and $\mathrm{Pb}$ in 11,14 and 17 infrapopulations of Gyliauchen volubilis, Procamallanus elatensis and Sclerocollum rubrimaris, respectively, calculated with respect to the selected host tissues.

\begin{tabular}{|c|c|c|c|c|c|c|c|c|}
\hline \multirow[t]{2}{*}{ Fish } & \multirow{2}{*}{$\begin{array}{c}\text { Parasite } \\
\text { infrapopulation } \\
\text { size }\end{array}$} & & \multicolumn{3}{|c|}{$\mathrm{BCF}=\left(C_{\text {[parasite] }} / C_{[\text {host tissue }]}\right)$} & \multicolumn{3}{|c|}{$\begin{array}{c}\mathrm{BCF}=\left(C_{\text {[parasite] }} / C_{\text {[host tissue }]}\right) \\
\mathrm{Pb}\end{array}$} \\
\hline & & & $\begin{array}{c}C_{\text {parasite }} / \\
C_{\text {fish intestines }}\end{array}$ & $\begin{array}{l}C_{\text {parasite }} / \\
C_{\text {fish liver }}\end{array}$ & $\begin{array}{c}C_{\text {parasite }} / \\
C_{\text {fish muscle }}\end{array}$ & $\begin{array}{c}C_{\text {parasite }} / \\
C_{\text {fish intestines }}\end{array}$ & $\begin{array}{l}C_{\text {parasite }} / \\
C_{\text {fish liver }}\end{array}$ & $\begin{array}{c}C_{\text {parasite }} / \\
C_{\text {fish muscle }}\end{array}$ \\
\hline $\begin{array}{l}\text { Infected with } \\
\quad \text { G. volubilis } \\
\quad(n=11)\end{array}$ & 63-159 & $\begin{array}{c}\text { Range } \\
\text { Mean } \pm \text { SD }\end{array}$ & $\begin{array}{l}1.0-2.4 \\
1.4 \pm 0.4\end{array}$ & $\begin{array}{l}0.3-0.8 \\
0.5 \pm 0.1\end{array}$ & $\begin{array}{l}1.6-3.3 \\
2.3 \pm 0.5\end{array}$ & $\begin{array}{l}1.0-2.7 \\
1.5 \pm 0.1\end{array}$ & $\begin{array}{l}0.2-0.5 \\
0.4 \pm 0.1\end{array}$ & $\begin{array}{l}3.1-7.3 \\
5.4 \pm 1.4\end{array}$ \\
\hline $\begin{array}{l}\text { Infected with } \\
\quad P . \text { elatensis } \\
(n=14)\end{array}$ & 55-179 & $\begin{array}{c}\text { Range } \\
\text { Mean } \pm \text { SD }\end{array}$ & $\begin{array}{l}1.0-2.3 \\
1.6 \pm 0.4\end{array}$ & $\begin{array}{l}0.4-0.8 \\
0.6 \pm 0.1\end{array}$ & $\begin{array}{l}1.7-3.9 \\
2.6 \pm 0.7\end{array}$ & $\begin{array}{l}1.0-2.3 \\
1.5 \pm 0.4\end{array}$ & $\begin{array}{l}0.2-0.7 \\
0.4 \pm 0.1\end{array}$ & $\begin{array}{l}3.7-8.5 \\
6.2 \pm 1.5\end{array}$ \\
\hline $\begin{array}{l}\text { Infected with } \\
\quad S . \\
\quad \text { rubrimaris } \\
\quad(n=17)\end{array}$ & $32-210$ & $\begin{array}{c}\text { Range } \\
\text { Mean } \pm \text { SD }\end{array}$ & $\begin{array}{l}203.8-405.6 \\
303.3 \pm 63.6\end{array}$ & $\begin{array}{l}104.1-147.9 \\
119.3 \pm 12.8\end{array}$ & $\begin{array}{l}367.5-980.2 \\
507.0 \pm 163.7\end{array}$ & $\begin{array}{l}52.9-117.1 \\
81.9 \pm 20.1\end{array}$ & $\begin{array}{l}20.1-28.6 \\
22.9 \pm 2.6\end{array}$ & $\begin{array}{l}469.3-1078.7 \\
731.8 \pm 160.7\end{array}$ \\
\hline
\end{tabular}

than those in fish muscle. As a result, bioconcentration factors corresponding to these parasites (Table 4) were relatively low and seemed to be insufficiently large or not sufficiently significant to consider them good bioindicators. In contrast, $\mathrm{Cd}$ and $\mathrm{Pb}$ concentrations in the body of $S$. rubrimaris were significantly higher than those in the intestines, liver and muscle of its fish host (Table 4). Therefore, the bioconcentration factors corresponding to $S$. rubrimaris seemed to be highly significant, since $\mathrm{Cd}$ concentrations in this acanthocephalan reached 405-, 147- and 980-fold higher than in fish intestines, liver and muscle, respectively, while those of $\mathrm{Pb}$ reached to 117-, 28- and 1087-fold higher than in these tissues, respectively.

\section{Discussion}

The siganid fish Siganus rivulatus and its intestinal helminth parasites, Gyliauchen volubilis, Procamallanus elatensis and Sclerocollum rubrimaris are common in the Red Sea [1-3, 15, 17, 41, 48]. As expected, these parasites have different abilities or capacities to accumulate trace metals in their bodies (see below).

In El-Mena Bay, mean $\mathrm{Cd}$ and $\mathrm{Pb}$ concentrations in the sediments were much greater than those in water. This is mostly because metals in aquatic environments are usually bound to suspended particles or adsorbed to particulate organic matter, which finally settle and accumulate in bottom sediments $[10,12,20,34,56]$. Therefore, metal concentrations are higher in sediment and usually exceed those of the overlying water by 3-5 orders of magnitude [20].

In the current study, $\mathrm{Cd}$ concentrations in the selected tissues of both non-infected and infected fishes were much lower than those of $\mathrm{Pb}$, and concentrations of both metals decreased in the order: liver $>$ intestines $>$ muscle. Metals mainly accumulated in metabolically active organs (e.g. liver, kidney, gills and intestines) $[16,31,32]$, and accumulated less in organs with relatively low metabolic activity (e.g. muscles) $[4,11,25,46]$. High concentrations of $\mathrm{Cd}$ and $\mathrm{Pb}$ in the hepatic tissue can possibly be attributed to its essential role in the accumulation, storage and detoxification of metals [9, 26, 38, 59].
Metals absorbed by the fish through its gills or its intestinal wall are carried by blood to the liver, where most of them are taken from blood to form organometallic complexes transferred with bile (bile complexes) into the small intestine, where they can be re-absorbed through the intestinal wall to enter the hepatic-intestinal cycle, or expelled with the fish faeces $[19,27,54]$. Intestinal helminths interfere with this cycle and ingest/absorb bile complexes according to their ability or capacity to do this [54]. In our study, both $G$. volubilis and $P$. elatensis contained $\mathrm{Cd}$ and $\mathrm{Pb}$ concentrations slightly higher than those in the intestines of their host fishes, and showed nonsignificant relationships with them. Thus, these parasites ingest/ absorb small amounts of bile complexes from the fish intestines. These amounts have very little effect on those that are normally absorbed across the intestinal wall of the fish, since $\mathrm{Cd}$ and $\mathrm{Pb}$ concentrations in the tissues of fishes infected with these parasites were slightly reduced compared to non-infected conspecifics. These results agree implicitly with some of the previous studies showing that intestinal trematodes [21, 30, 42, 49] and nematodes [36, 39, 53, 57] of fishes have limited abilities or capacities to accumulate trace metals in their bodies; some authors considered nematodes good sentinels for metal pollution in aquatic environments [7, 33, 35, 44].

Unlike $G$. volubilis and $P$. elatensis, $S$. rubrimaris contained $\mathrm{Cd}$ and $\mathrm{Pb}$ concentrations much higher than those in the fish intestines, and showed significant positive relationships with them. Acanthocephalans have a strong ability and large capacity to absorb bile complexes via their tegument with higher efficiency than the intestinal wall of the fish host [50, 54]. Consequently, the amount of bile complexes that are normally re-absorbed by the intestinal wall is considerably reduced, and thereby, $\mathrm{Cd}$ and $\mathrm{Pb}$ concentrations in the intestines, liver and muscle of acanthocephalan-infected fishes were dramatically reduced compared to non-infected conspecifics. Acanthocephalans are now well documented as good sentinels for trace metal pollution in aquatic environments [13, 23, 28, 29, 36, 39, 51-53].

In the present study, no significant relationships were found between $\mathrm{Cd}$ and $\mathrm{Pb}$ concentrations in fish intestines and $G$. volubilis or $P$. elatensis infrapopulation size, or between 
$\mathrm{Cd}$ and $\mathrm{Pb}$ concentrations in $G$. volubilis or P. elatensis and its infrapopulation size. This showed that there is no evidence for interspecific competition (between the fish host and G. volubilis or P. elatensis) or for intraspecific competition (among parasite individuals) for accumulating these metals. There were clear negative relationships between $\mathrm{Cd}$ or $\mathrm{Pb}$ concentrations in fish intestines and $S$. rubrimaris infrapopulation size, i.e. as the infrapopulation size of $S$. rubrimaris in the intestines of S. rivulatus increases, the concentrations of both $\mathrm{Cd}$ and $\mathrm{Pb}$ in the intestines significantly decrease. This decrease with the increase in infrapopulation size strongly suggests interspecific competition (between the fish host and its acanthocephalan parasite) for accumulating these metals. There were also clear negative relationships between $\mathrm{Cd}$ or $\mathrm{Pb}$ concentrations in $S$. rubrimaris and its infrapopulation size, i.e. as the infrapopulation size of $S$. rubrimaris increased, the concentration of both $\mathrm{Cd}$ and $\mathrm{Pb}$ in its individuals significantly decreased. This decrease with the increase in infrapopulation size strongly suggests intraspecific competition (between parasite individuals) for absorbing available metals from fish intestines [57]. Such competition for host limited resources is common in acanthocephalan infrapopulations [24, 45, 47].

Because both $G$. volubilis and P. elatensis accumulate few amounts of metals in their bodies, bioconcentration factors corresponding to them were significantly low, and both are considered herein as weak bioindicators for trace metal pollution in marine environments. In contrast, S. rubrimaris accumulates significantly higher amounts of metal in its body. Therefore, bioconcentration factors corresponding to this acanthocephalan seemed to be highly significant, since Cd concentrations in its body reached 405-, 147- and 980-fold higher than in fish intestines, liver and muscle, respectively, while those of $\mathrm{Pb}$ reached to 117-, 28- and 1087-fold higher than in these tissues, respectively. These values appear to be highly significant, since in marine environments only minute amounts of trace metals are found as free ions (hydrated) or biologically available for uptake by organisms [37].

Of the present three host-parasite systems, S. rivulatus$G$. volubilis, $S$. rivulatus-P. elatensis and $S$. rivulatus-S. rubrimaris, only the later seems promising for biomonitoring of metal pollution in the Red Sea. Sclerocollum is a small acanthocephalan genus and currently includes three species [5]: S. robustum (Edmonds 1964) Schmidt et Paperna 1978, S. rubrimaris Schmidt et Paperna 1978, and S. saudii Al-Jahdali 2010. The second and the third are endemic to the Red Sea. Recently and as in the present study, $S$. saudii was considered a good sentinel for biomonitoring trace metal pollution in the Red Sea [23].

Finally, our results are completely consistent with the previous studies [13, 39, 42, 52, 53] showing that gutless helminth parasites which take up their nutrients via their tegument from fish intestines, such as acanthocephalans and cestodes, are more appropriate sentinels for trace metal pollution than other helminths which have a gastro-intestinal tract, i.e. trematodes and nematodes.

\section{Competing interests}

The author declares that he has no conflict of interest.

\section{Funding}

We are very grateful to King Abdulaziz University, Saudi Arabia, for continued encouragement and support.

Acknowledgements. I am very grateful to Prof. Dr Reda Hassanine (Biological Sciences Department, Rabigh-Faculty of Science and Arts, King Abdulaziz University, Saudi Arabia) for his useful comments. I would like to extend my appreciation to the staff of the Red Sea Diving Center, Sharm El-Sheikh, South Sinai, Egypt, for their help during the collection of the material.

\section{References}

1. Al-Jahdali MO. 2012. Infrapopulations of Procamallanus elatensis Fusco \& Overstreet, 1979 (Nematoda: Camallanidae) in the rabbitfish Siganus rivulatus (Teleostei, Siganidae) from the Saudi coast of the Red Sea. Journal of Helminthology, 86, 378-385.

2. Al-Jahdali MO. 2012. Infrapopulations of Gyliauchen volubilis Nagaty, 1956 (Trematoda: Gyliauchenidae) in the rabbitfish Siganus rivulatus (Teleostei: Siganidae) from the Saudi coast of the Red Sea. Parasite, 19, 227-238.

3. Al-Jahdali MO, Hassanine El-Said RM. 2012. The life cycle of Gyliauchen volubilis Nagaty, 1956 (Digenea: Gyliauchenidae) from the Red Sea. Journal of Helminthology, 86, 165-172.

4. Al-Khatani AM. 2009. Accumulation of heavy metals in Tilapia fish (Oreochromis niloticus) from Al-Khadoud Spring, Al-Hassa, Saudi Arabia. American Journal of Applied Sciences, 6, 2024-2029.

5. Amin O. 2013. Classification of the Acanthocephala. Folia Parasitologica, 60, 273-305.

6. Amini Z, Pazooki J, Abtahi B, Shokri MR. 2013. Bioaccumulation of $\mathrm{Zn}$ and $\mathrm{Cu}$ in Chasar bathybius (Gobiidae) tissue and its nematode parasite Dichelyne minutus, southeast of the Caspian Sea. Indian Journal of Geo-Marine Sciences, 42, 196-200. http://hdl.handle.net/123456789/16930.

7. Baruš V, Jarkovsky J, Prokeš M. 2007. Philometra ovata (Nematoda: Philometroidea): A potential sentinel species of heavy metal accumulation. Parasitology Research, 100, 929.

8. Bayoumy EM, Osman HAM, El-Bana LF, Hassanain MA. 2008. Monogenean parasites as bioindicators for heavy metals status in some Egyptian Red Sea fishes. Global Veterinaria, 2, 117-122. http://idosi.org/gv/gv2(3)08/5.pdf.

9. Buckley JT, Roch M, McCarter JA, Rendell CA, Matheson AT. 1992. Chronic exposure of Coho salmon to sublethal concentration of copper. Effect on growth, on accumulation out distribution of copper and on copper tolerance. Comparative Biochemistry and Physiology, 72C, 15-19.

10. Campbell KR. 1994. Concentrations of heavy metals associated with urban runoff in fish living in stormwater treatment ponds. Archives of Environmental Contamination and Toxicology, 27, 352-356.

11. Canli M, Ay O, Kalay M. 1998. Levels of heavy metals (Cd, Pb, $\mathrm{Cu}$, and $\mathrm{Ni}$ ) in tissue of Cyprinus Carpio, Barbus Capito and Chondrostoma regium from the Seyhan River. Turkish Journal of Zoology, 22, 149-157. http://dergipark.gov.tr/download/ article-file/135485.

12. Dauvalter VA. 1998. Heavy metals in the bottom sediments of the Inari-Pasvik lake-river system. Water Resources, 25, 451-457.

13. De Buron I, James E, Riggs-Gelasco P, Ringwood AH, Rolando E, Richardson D. 2009. Overviewof the status of heavymetal accumulation by helminthes with a note on the use 
of in vitro culture of adult acanthocephalans to study the mechanisms of bioaccumulation. Neotropical Helminthology, 3 , 101-110. http://sisbib.unmsm.edu.pe/bvrevistas/neohel/v3n2/ contenido.htm.

14. Demirezen D, Uruc K. 2006. Comparative study of trace elements in certain fish, meat and meat products. Meat Science, 74, 255-260.

15. Diamant A. 1989. Ecology of the acanthocephalan Sclerocollum rubrimaris Schmidt and Paperna, 1978 (Rhadinorhynchidae: Gorgorhynchinae) from wild populations of rabbitfish (genus Siganus) in the northern Red Sea. Journal of Fish Biology, 34, 387-397.

16. Dural M, Lugal Göksu MZ, Özak AA, Derici B. 2006. Bioaccumulation of some heavy metals in different tissues of Dicentrarchus labrax L, 1758, Sparus aurata L, 1758 and Mugil cephalus L, 1758 from the Çamllk lagoon of the eastern cost of Mediterranean (Turkey). Environmental Monitoring and Assessment, 118, 65-74.

17. Fusco AC, Overstreet RM. 1979. Two camallanid nematodes from Red Sea fishes including Procamallanus elatensis sp. nov. from siganids. Journal of Natural History, 13, 35-40.

18. Goater TM, Goater CP, Esch GW. 2013. Parasitism: the diversity and ecology of animal parasites. Cambridge: Cambridge University Press. p. 510.

19. Grahl K. 1990. Erkennung von Schadstoffeinflussen auf die Gesundheit von Fischen mittels Gallendiagnostik, in DVG/ Fachgruppe. Fischkrankheiten: Tagung der Fachgruppe Fischkrankheiten, Schmiedefeld/Thüringen. p. 240-243. Germany.

20. Gurunadha Rao VVS, Jain CK, Prakash BA, Kumar KM. 2008. Heavy metal speciation study of sediments in Hussainsagar Lake, Greater Hyderabad, India, in Proceedings of Taal 2007: The 12th World Lake Conference, 2098-2104.

21. Hassan AA, Moharram S, El Helaly H. 2018. Role of parasitic helminths in bioremediating some heavy metal accumulation in the tissues of Lethrinus mahsena. Turkish Journal of Fisheries and Aquatic Sciences, 18, 435-443.

22. Hassan AH, Al-Zanbagi NA, Al-Nabati EA. 2016. Impact of nematode helminthes on metal concentrations in the muscles of Koshar fish, Epinephelus summana, in Jeddah, Saudi Arabia. Journal of Basic \& Applied Zoology, 74, 56-61.

23. Hassanine RM, Al-Hasawi ZM, Hariri MS, Touliabah HEl-S. 2018. Sclerocollum saudii Al-Jahdali, 2010 (Acanthocephala: Cavisomidae) as a sentinel for heavy-metal pollution in the Red Sea. Journal of Helminthology. (in press).

24. Hassanine RM, Al-Jahdali MO. 2008. Intraspecific densitydependent effects on growth and fecundity of Diplosentis nudus (Harada, 1938) Pichelin et Cribb, 2001 (Acanthocephala: Cavisomidae). Acta Parasitologica, 53, 289-295.

25. Heath AG. 1987. Water pollution and fish physiology. Florida, USA: CRC Press. p. 384.

26. Heath AG. 1990. Water pollution and fish physiology. UK: CRC Press (Taylor \& Francis group). p. 254.

27. Hofer R, Lackner R. 1995. Fischtoxikologie-Theorie und Praxis. Jena, Germany: Fischer Verlag. p. 164.

28. Jankovská I, Miholová D, Lukešová D, Kalous L, Válek P, Romočuský Š, Vadlejch J, Petrtýl M, Langrová I, Čadková Z. 2012. Concentrations of $\mathrm{Zn}, \mathrm{Mn}, \mathrm{Cu}$ and $\mathrm{Cd}$ in different tissues of perch (Perca fluviatilis) and in perch intestinal parasite (Acanthocephalus lucii) from the stream near Prague (Czech Republic). Environmental Research, 112, 83-85.

29. Jirsa F, Leodolter-Dvorak M, Krachler R, Frank C. 2008. Heavy metals in the nase, Chondrostoma nasus (L. 1758), and its intestinal parasite Caryophyllaeus laticeps (Pallas 1781) from Austrian Rivers: Bioindicative aspects. Archives of Environmental Contamination and Toxicology, 55, 619-626.
30. Jordi T, Hichem K, Catarina E, Lassad N, Jordi M. 2014. Total mercury and selenium concentrations in Sarpa salpa and Balistes capriscus and in their respective Digenean endoparasites Robphildollfusium fractum and Neoapocreadium chabaudi from Tunisia. Acta Parasitologica, 59, 580-585.

31. Kelle HI, Ngbede EO, Oguezi VU, Ibekwe FC. 2015. Determination of heavy metals in fish (Clarias gariepinus) organs from Asaba Major Markets, Delta State, Nigeria. American Chemical Science Journal, 5, 135-147.

32. Kenšova R, Čelehovska O, Doubravova J, Svobodova Z. 2010. Concentration of metals in tissues of fish from the Vestonice Reservoir. Acta Veterinaria Brno, 79, 335-345.

33. Khaleghzadeh-Ahangar H, Malek M, McKenzie K. 2011. The parasitic nematodes Hysterothylacium sp. type MB larvae as bioindicators of lead and cadmium: a comparative study of parasite and host tissues. Parasitology, 138, 1400-1405.

34. Luorna SN. 1990. Processes affecting metal concentrations in estuarine and coastal marine sediments, in Heavy metals in the marine environment, Furness RW, Rainbow PS, Editors. CRC Press (Taylor \& Francis group): Florida, USA. p. 1-66. http:// pubs.er.usgs.gov/publication/70175382.

35. Mazhar R, Shazili NA, Harrison FS. 2014. Comparative study of the metal accumulation in Hysterothalycium reliquens (nematode) and Paraphilometroides nemipteri (nematode) as compared with their doubly infected host, Nemipterus peronii (Notched threadfin bream). Parasitology Research, 113, 3737-3743.

36. Mehdi N, Mahdi F. 2015. Helminthic parasites as heavy metal bioindicators in aquatic ecosystems. Medical Laboratory Journal, 9, 26-32.

37. Merian E. 2004. Elements and their compounds in the environment. Occurrence, analysis and biological relevance. Wiley: Weinheim, Germany.

38. Miller PA, Munkittrick KR, Dixon DG. 1992. Relationship between concentrations of copper and zinc in water, sediment, benthic invertebrates and tissues of white sucker (Catastomus commersoni) at metal-contaminated sites. Canadian Journal of Fisheries and Aquatic Sciences, 49, 978-984.

39. Nachev M, Schertzinger G, Sures B. 2013. Comparison of the metal accumulation capacity between the acanthocephalan Pomphorhynchus laevis and larval nematodes of the genus Eustrongylides sp. infecting barbel (Barbus barbus). Parasites \& Vectors, 6, 21.

40. Nachev M, Sures B. 2016. Environmental Parasitology: parasites as accumulation bioindicators in the marine environment. Journal of Sea Research, 113, 45-50.

41. Nagaty HF. 1956. Trematodes of fishes from the Red Sea. Part 7. On two gyliauchenids and three allocreadiids, including four new species. Journal of Parasitology, 42, 523-527. https://www. jstor.org/stable/3274451.

42. Najm M, Fakhar M. 2015. Helminthic parasites as heavy metal bioindicators in aquatic ecosystems. Medical Laboratory Journal, 9, 26-32.

43. Oregioni B, Aston SR. 1984. The determination of selected trace metals in marine sediments by flameless/flame atomic absorption spectrophotometry. IAEA Monaco Laboratory: Monaco. Internal Report.

44. Pascual S, Abollo E. 2003. Accumulation of heavy metals in the whaleworm Anisakis simplex s.l. (Nematoda: Anisakidae). Journal of the Marine Biological Association of the United Kingdom, 83, 905-906.

45. Poulin R. 2006. Evolutionary ecology of parasites. 2nd Edn. Princeton, NJ: Princeton University Press. p. 360.

46. Roesijadi G, Robinson WE. 1994. Metal regulation in aquatic animals: mechanism of uptake, accumulation and release, in Aquatic toxicology (molecular, biochemical and cellular 
perspectives), Malins DC, Ostrander GK, Editors. Lewis Publishers: London, UK. p. 385-420.

47. Sasal P, Jobet E, Faliex E, Morand S. 2000. Sexual competition in an acanthocephalan parasite of fish. Parasitology, 120, $65-69$.

48. Schmidt GD, Paperna I. 1978. Sclerocollum rubrimaris gen. et sp. n. (Rhadinorhynchidae: Gorgorhynchinae), and other Acanthocephala of marine fishes from Israel. Journal of Parasitology, 64, 846-850.

49. Shahat MA, Amer OSO, AbdAllah AT, Abdelsater N, Moustafa MA. 2011. The distribution of certain heavy metals between intestinal parasites and their fish hosts in the River Nile at Assuit Province, Egypt. Egyptian Journal of Hospital Medicine, 43, 241-257. http://egyptianjournal.xyz/.

50. Sures B. 2002. Competition for minerals between Acanthocephalus lucii and its definitive host perch (Perca fluviatilis). International Journal of Parasitology, 32, 1117-1122.

51. Sures B. 2003. Accumulation of heavy metals by intestinal helminthes in fish an overview and perspective. Parasitology, 126(Suppl), 553-560.

52. Sures B. 2004. Environmental parasitology: Relevancy of parasites in monitoring environmental pollution. Trends in Parasitology, 20, 170-177.

53. Sures B, Nachev M, Selbach C, David J, Marcogliese DJ. 2017. Parasite responses to pollution: What we know and where we go in 'Environmental Parasitology'. Parasites \& Vectors, 10, 65.

54. Sures B, Siddall R. 1999. Pomphorhynchus laevis: The intestinal acanthocephalan as a lead sink for its fish host, chub (Leuciscus cephalus). Experimental Parasitology, 93, 66-72.
55. Sures B, Siddall R, Taraschewski H. 1999. Parasites as accumulation indicators of heavy metal pollution. Parasitology Today, 15, 16-21.

56. Tekin-Ozan S, Kir İ. 2008. Concentrations of some heavy metals in tench (Tinca tinca L., 1758), its endoparasite (Ligula intestinalis L., 1758), sediment and water in Beyşehir Lake, Turkey. Polish Journal of Environmental Studies, 17, 597-603.

57. Tenora F, Barus V, Kracmar S, Dvořáček J. 2000. Concentrations of some heavy metals in Ligula intestinalis plerocercoids (Cestoda) and Philometra ovate (Nematoda) compared to some of their hosts (Osteichthyes). Helminthologia, 37, 15-18.

58. Wakawa RJ, Uzairu A, Kagbu JA, Balarabe ML. 2008. Impact assessment of effluent discharge on physicochemical parameters and some heavy metal concentrations in surface water of river challawa Kano, Nigeria. African Journal of Pure and Applied Chemistry, 2, 100-106. http://www.academicjournals. org/AJPAC.

59. Yousafzai AM, Khan AR, Shakoori AR. 2009. Trace metal accumulation in the liver of an endangered South Asian fresh water fish dwelling in sub-lethal pollution. Pakistan Journal of Zoology, 41, 35-41.

60. Zimmermann S, Menzel C, Berner Z, Eckhardt JD, Stüben D, Alt F, Messerschmidt J, Taraschewski H, Sures B. 2001. Trace analysis of platinum in biological samples: A comparison between high resolution inductively coupled plasma mass spectrometry (HR-ICP-MS) following microwave digestion and adsorptive cathodic stripping voltammetry (ACSV) after high pressure ashing. Analytica Chimica Acta, 439(Suppl. 2), 203-209.

Cite this article as: Al-Hasawi ZM. 2019. Environmental Parasitology: intestinal helminth parasites of the siganid fish Siganus rivulatus as bioindicators for trace metal pollution in the Red Sea. Parasite 26, 12.

\section{PARASTTE}

An international open-access, peer-reviewed, online journal publishing high quality papers on all aspects of human and animal parasitology

Reviews, articles and short notes may be submitted. Fields include, but are not limited to: general, medical and veterinary parasitology; morphology, including ultrastructure; parasite systematics, including entomology, acarology, helminthology and protistology, and molecular analyses; molecular biology and biochemistry; immunology of parasitic diseases; host-parasite relationships; ecology and life history of parasites; epidemiology; therapeutics; new diagnostic tools.

All papers in Parasite are published in English. Manuscripts should have a broad interest and must not have been published or submitted elsewhere. No limit is imposed on the length of manuscripts.

Parasite (open-access) continues Parasite (print and online editions, 1994-2012) and Annales de Parasitologie Humaine et Comparée (1923-1993) and is the official journal of the Société Française de Parasitologie. 